\title{
Identification and phylogenetic analysis of contagious ecthyma virus from camels (Camelus dromedarius) in Iran
}

\begin{tabular}{|c|c|}
\hline \multicolumn{2}{|c|}{$\begin{array}{l}\text { Authors: } \\
\text { Ahmad Oryan }{ }^{1} \text { (D) } \\
\text { Mahboobe Mosadeghhesari }^{1} \\
\text { Saeed Zibaee } \\
\text { Ali Mohammadi }^{1} \text { (D) }\end{array}$} \\
\hline \multicolumn{2}{|c|}{$\begin{array}{l}\text { Affiliations: } \\
{ }^{1} \text { Department of } \\
\text { Pathobiology, Shiraz } \\
\text { University, Iran }\end{array}$} \\
\hline \multicolumn{2}{|c|}{$\begin{array}{l}{ }^{2} \text { Razi Vaccine and Serum } \\
\text { Research Institute, } \\
\text { Mashhad, Iran }\end{array}$} \\
\hline \multicolumn{2}{|c|}{$\begin{array}{l}\text { Corresponding author: } \\
\text { Ahmad Oryan, } \\
\text { oryan1215@gmail.com }\end{array}$} \\
\hline \multicolumn{2}{|c|}{$\begin{array}{l}\text { Dates: } \\
\text { Received: } 13 \text { May } 2016 \\
\text { Accepted: } 25 \text { Jan. } 2017 \\
\text { Published: } 24 \text { Mar. } 2017\end{array}$} \\
\hline \multicolumn{2}{|c|}{$\begin{array}{l}\text { How to cite this article: } \\
\text { Oryan, A., Mosadeghhesari, } \\
\text { M., Zibaee, S. \& Mohammadi, } \\
\text { A., 2017, 'Identification and } \\
\text { phylogenetic analysis of } \\
\text { contagious ecthyma virus } \\
\text { from camels (Camelus } \\
\text { dromedarius) in Iran', } \\
\text { Onderstepoort Journal of } \\
\text { Veterinary Research } 84(1), \\
\text { a1257. https://doi. } \\
\text { org/10.4102/ojvr.v84i1.1257 }\end{array}$} \\
\hline \multicolumn{2}{|c|}{$\begin{array}{l}\text { Copyright: } \\
\text { (C) 2017. The Authors. } \\
\text { Licensee: AOSIS. This } \\
\text { is licensed under the } \\
\text { Creative Commons } \\
\text { Attribution License. }\end{array}$} \\
\hline \multicolumn{2}{|l|}{ Read online: } \\
\hline 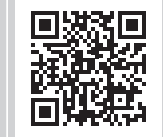 & $\begin{array}{l}\text { Scan this QR } \\
\text { code with your } \\
\text { smart phone or } \\
\text { mobile device } \\
\text { to read online. }\end{array}$ \\
\hline
\end{tabular}

Contagious ecthyma is a highly contagious disease affecting domestic and wild ruminants such as sheep, goats and camels. The identification and characterisation of a parapoxvirus (PPV) infecting camels is described here. The virus was detected in dromedary camels (Camelus dromedarius) from Kerman and Shiraz in Iran. PPV-specific amplification by polymerase chain reaction (PCR) further confirmed that the disease was associated with PPV infection. Phylogenetic analysis of ORF011 (B2L) gene sequences showed $99.79 \%$ and $82.13 \%$ similarity of the PPV identified in this study with the Jodhpur isolate and the bovine papular stomatitis virus (BPSV) isolates (CE41), respectively. Moreover, phylogenetic analysis of the ORF045 gene indicated that the Shiraz sample was in all probability closely related to VR634 and to F00.120R and PCPV776. In conclusion, the results suggest that camel PPV (CPPV) is a likely cause of contagious ecthyma in dromedary camels in Iran.

\section{Introduction}

Camel contagious ecthyma (CCE), also known as orf, Auzdik or contagious pustular dermatitis, is a worldwide skin disease in camelids characterised by self-limiting proliferative lesions (Nagarajan et al. 2010). These nodular lesions followed by papules and vesicles mostly appear around the mouth, nares, lips and eyes or in some instances, other sites (Abubakr et al. 2007; Venkatesan et al. 2010). They then develop into scabs and healing may take up to 20 days - 30 days or even more (Nagarajan et al. 2010). This disease is caused by pseudocowpox virus (PCPV) in cattle, whereas its main causative agent in sheep, goats, camels and humans is Orf virus (ORFV) (Davari et al. 2013; Nagarajan et al. 2010). However, PCPV has been reported as the etiologic agent of the disease in camels (Abubakr et al. 2007; Nagarajan et al. 2010). The ORFV or CCE virus belongs to the genus parapoxvirus (PPV), the subfamily Chordopoxvirinae of the Poxviridae family (Fleming, Wise \& Mercer 2015; Harvey et al. 2015; Klein \& Tryland 2005; Venkatesan et al. 2010). Morbidity is high, whereas its mortality and fatality rates are low to moderate. Nevertheless, this debilitating disease can lead to high mortality in younger animals due to secondary infections and trouble in suckling and eating (Hosamani et al. 2006). The genome of ORFV contains a linear double-stranded DNA molecule of approximately $134 \mathrm{kbp}-139 \mathrm{kbp}$ in length (Hautaniemi et al. 2010; Li et al. 2013; Rovozze \& Burke 1973). The genes at the terminal ends are mostly responsible for viral replication, whereas those located in the central sites are essential for virus virulence and pathogenesis ( $\mathrm{Li}$ et al. 2013). For instance, the well-conserved ORF045 gene encodes the late transcription factor VLTF-1, whereas the envelope or ORF011 (B2L) gene encodes a highly immunogenic envelope protein stimulating a strong antibody response (Kottaridi et al. 2006; Zhang et al. 2014). ORFV is sometimes transmitted to humans via direct contact with the infected animal (Torfason \& Gunadottir 2002). Clinical signs of pox, contagious ecthyma and papillomatosis are similar and difficult to distinguish (Khalafalla, Al-Busada \& El-Sabagh 2015a; Khalafalla et al. 2015b; Mosadeghhesari et al. 2014; Nagarajan et al. 2010). Polymerase chain reaction (PCR) and sequencing methods may be useful for genetic characterisation and classification of PPVs (Inoshima et al. 2001; Khalafalla et al. 2015a). The PPVs in Iranian dromedaries (Camelus dromedarius) have not yet been characterised at the genetic level, whereas their relationship to PPVs in domestic animals also remains unclear. Also, the ORF011 and ORF045 genes of camel PPV (CPPV) were used for viral detection, examining the outbreak of CPPV infection in camels by PCR and for phylogenetic analysis.

\section{Material and methods}

\section{Sampling}

Sixty skin samples were collected from two outbreaks of ORFV which occurred in 2013 in dromedary camels of Shiraz and Kerman cities, southern and eastern Iran, respectively. Biopsies 
of the skin and the lip of the affected camels were sent to Razi Research Vaccine and Serum Institute. The samples collected from the diseased camels were analysed for PCR assay.

\section{DNA extraction and primer design}

DNA of the samples from the skin and lip lesions was extracted by High Pure ${ }^{\circledR}$ Extraction Kit (Roche Diagnostics $\mathrm{GmbH}$, Mannheim, Germany). Briefly, $50 \mathrm{mg}$ of the tissue samples was homogenised in $200 \mu \mathrm{L}$ of phosphate buffer saline (PBS) and mixed with $200 \mu \mathrm{L}$ of binding buffer and $50 \mu \mathrm{L}$ of proteinase $\mathrm{K}$ then incubated at $72{ }^{\circ} \mathrm{C}$ for $10 \mathrm{~min}$. The process was continued according to the manufacturer's instructions.

According to Inoshima, Morooka and Sentsui (2000), a set of primers including pan-parapoxvirus primer 1 (PPP-1) and PPP-4 were applied based on the sequence of the ORF011 gene. The sequences of PPP- 1 and PPP- 4 were $5^{\prime}$-gtc gtc cac gat gag cag ct- $3^{\prime}$ and 5'-tac gtg gga agc gcc tcg ct- $3^{\prime}$, respectively (Inoshima et al. 2000). In addition, the primers 045F ( $5^{\prime}$-cct act tct cgg agt tca gc-3') and 045R (5'-gca gca ctt ctc ctc gta g- $\left.3^{\prime}\right)$ were applied based on the sequence of 045 gene of ORFV, isolate OV-SA00 (accession no. AY186732) (Delhon et al. 2004).

\section{Polymerase chain reaction}

For amplification of the ORF011 gene, the PCR assay was carried out as follows: $1 \mu \mathrm{g}$ of DNA isolated from the infected or uninfected cells was added to $50 \mu \mathrm{L}$ of the PCR mixture containing $0.2 \mathrm{mM}$ primers (PPP-1 and PPP-4), $0.2 \mathrm{mM}$ dATP, $\mathrm{dCTP}$, dGTP and dTTP, $10 \mathrm{mM}$ Tris- $\mathrm{HCl}(\mathrm{pH} 8.3), 50 \mathrm{mM}$ $\mathrm{KCl}, 1.5 \mathrm{mM} \mathrm{MgCl}$ and $1 \mathrm{U}$ of AmpliTaq Gold DNA polymerase. DNA was amplified with a DNA thermal cycler by a two-step reaction. The mixture was denatured at $95{ }^{\circ} \mathrm{C}$ for $9 \mathrm{~min}$, five cycles of $94{ }^{\circ} \mathrm{C}$ for $1 \mathrm{~min}, 50^{\circ} \mathrm{C}$ for $1 \mathrm{~min}, 72^{\circ} \mathrm{C}$ for $1 \mathrm{~min}, 25$ repeated cycles at $94{ }^{\circ} \mathrm{C}$ for $1 \mathrm{~min}, 55^{\circ} \mathrm{C}$ for $1 \mathrm{~min}$ and finally $72{ }^{\circ} \mathrm{C}$ for $1 \mathrm{~min}$ (Inoshima et al. 2000).

For amplification of the ORF045 gene, the PCR assay was carried out in a reaction mixture of $50 \mu \mathrm{L}$ containing $1 \mu \mathrm{g}$ $(10 \mu \mathrm{L})$ of extracted DNA, $5 \mu \mathrm{L}$ of $\mathrm{dNTP}(10 \mathrm{mM}), 5 \mu \mathrm{L}$ of 10x PCR buffer, $2 \mu \mathrm{L}$ of $\mathrm{MgCl}_{2}(50 \mathrm{mM}), 2 \mathrm{U} /$ tube of Taq polymerase, 50 pmol of each of the primers and $33 \mu \mathrm{L}$ of distilled water. Forty cycles of denaturation (at $95{ }^{\circ} \mathrm{C}$, for $10 \mathrm{~s}$ ), annealing (at $47^{\circ} \mathrm{C}$ for $10 \mathrm{~s}$ ) and extension (at $74^{\circ} \mathrm{C}$ for $10 \mathrm{~s})$ were followed by a $15-\mathrm{min}$ incubation at $78{ }^{\circ} \mathrm{C}$ to final extension of the primers. The amplification products $(10 \mu \mathrm{L})$ were analysed by $2 \%$ agarose gel in Tris-boric acid-EDTA (TBE) buffer and stained with SYBR Green $(1 \mu \mathrm{g} / \mathrm{mL})$ (Kottaridi et al. 2006). The amplicons were visualised using a UV transilluminator 'gel doc' system.

\section{Sequencing of the polymerase chain reaction products containing ORF011 and ORF045 genes}

The PCR products with the expected sizes (594 bp and $393 \mathrm{bp}$ ) were purified from the gel using the Bioneer (Daejeon, South Korea) gel extraction kit, according to the manufacturer's procedures, and then were sequenced by the use of neighbour-joining method (Bioneer).

\section{Phylogenetic analysis}

Comparison among the isolates of this study and those of the ORFV available in GenBank, NCBI database, was made using the online BLAST program. Sequence identities of the nucleotides were analysed by CLC program version 5.5 . The sequences were assembled into multiple sequence alignment. A phylogenetic tree derived from the nucleotide sequences was constructed for the ORFV, using neighbour-joining method of CLC program version 5.5. The sequences of the ORF011 and ORF045 genes of ORFV used in phylogenetic analysis are presented in Tables 1 and 2.

\section{Results}

\section{Polymerase chain reaction and DNA sequencing}

The PCR method was performed to amplify the ORF011 gene. This method successfully detected the DNA from members of the PPV genus and was able to diagnose the ORFV infection. To confirm the causative agent, a partial region of the ORF011 gene was amplified. The primers PPP-1 and PPP-4 were described as the universal primers to amplify most species of ORFVs that have been used in the present study. A 594-bp product representing the region (157 nt - $750 \mathrm{nt}$ ) of the ORF011 gene was amplified from Shiraz samples. The 594-bp DNA fragment was sequenced and the nucleotide sequence data confirmed ORFV. Another PCR test was performed on DNA purified from Kerman samples as template and the pair of 045F/045R primers to amplify the ORF045 gene. PCR resulted in the amplification of the gene ORF045 with an expected DNA fragment (392 bp).

\section{Phylogenetic analysis}

The samples used in this study included Kerman (MSOKE) and Shiraz (MSOSH) isolates. The sequences aligned with MSOKE and MSOSH were based on the ORF011 gene (Table 1) and the gene ORF045 (Table 2), respectively. As stated previously, the samples of this study and the previous isolates were aligned and the phylogenetic tree was drawn by CLC program version 5.5. Results of the phylogenetic tree related to the ORF011 gene have been shown in Figure 1a that there is a main clade or lineage containing SV252/11 and other isolates. A branch of the main clade contains three clades including MSOKE and CCE virus isolate from Jodhpur, MSOKE/Jodhpur isolate sister to bovine papular stomatitis virus (BPSV) isolate CE41, and Clade MSOKE/Jodhpur and CE41 sisters to Brazil isolates. MSOKE had 99.77\% and $82.13 \%$ similarity with Jodhpur and CE41 isolates, respectively. In addition, MSOKE had minimum distance (0.20) to Jodhpur and CE41. The results of phylogenetic tree from gene ORF045 with two principal clades analysis are shown in Figure $1 \mathrm{~b}$ including clade ORFB and other sequences, clade GQ329670/MSOSH and GQ329669/ HM589037 while another branch contains other sequences. Indeed, MSOSH was closely related to PCPV from Finland 
TABLE 1: Nucleotide sequences of ORF011 gene that were aligned in the samples of the present study.

\begin{tabular}{|c|c|c|c|c|c|}
\hline Serial number & Virus isolate (strain) & Organism & Country & Reference & Accession number \\
\hline 1 & SV252/11 & ORFV & Brazil & Schmidt et al. (2013) & JX485997.1 \\
\hline 2 & SV178/12 & ORFV & Brazil & Schmidt et al. (2013) & JX485994.1 \\
\hline 3 & MT-05 & ORFV & Brazil & DS & JN613809.1 \\
\hline 4 & MT-05 & ORFV & Brazil & Abrahao et al. (2009) & FJ665818.1 \\
\hline 5 & Ovino_Patos & ORFV & Brazil & Schmidt et al. (2013) & JX485993.1 \\
\hline 6 & Cangucu & ORFV & Brazil & Schmidt et al. (2013) & JX485989.1 \\
\hline 8 & CE41 & Bovine papular stomatitis virus & Sudan & Dal Pozzo et al. (2011) & JN171861.1 \\
\hline 9 & PA11 & ORFV & Brazil & De Oliveira et al. (2012) & JQ349520.1 \\
\hline 10 & SV29/12 & ORFV & Brazil & Schmidt et al. (2013) & JX485991.1 \\
\hline 11 & SV26/12 & ORFV & Brazil & Schmidt et al. (2013) & JX485988.1 \\
\hline 12 & SV561/11 & ORFV & Brazil & Schmidt et al. (2013) & JX485990.1 \\
\hline 13 & SV27/12 & ORFV & Brazil & Schmidt et al. (2013) & $J X 485995.1$ \\
\hline 14 & SV28/12 & ORFV & Brazil & Schmidt et al. (2013) & JX485996.1 \\
\hline 16 & PCPV776 & Pseudocowpox virus & Austria & DS & HM589036.1 \\
\hline 17 & $48 / 01$ & Pseudocowpox virus & Austria & DS & AY636048.1 \\
\hline 18 & Cam/09 & ORFV & India & DS & GU460370.1 \\
\hline 19 & NE1 & ORFV & Brazil & Abrahao et al. (2009) & FJ665819.1 \\
\hline 20 & NE1 & ORFV & Brazil & DS & JN613810.1 \\
\hline 21 & Bahia & ORFV & Brazil & Schmidt et al. (2013) & JX485987.1 \\
\hline 22 & Caprino_SJE & ORFV & Brazil & Schmidt et al. (2013) & JX485992.1 \\
\hline 23 & Taiping & ORFV & Taiwan & Chan et al. (2009) & EU327506.1 \\
\hline
\end{tabular}

ORFV, Orf virus; DS, direct submission.

TABLE 2: Nucleotide sequences of ORF045 gene that were aligned in the samples of the present study.

\begin{tabular}{|c|c|c|c|c|c|}
\hline Serial number & Virus isolate (strain) & Organism & Country & Reference & Accession number \\
\hline 1 & BV- AR02/ORFB & Bovine papular stomatitis virus & United States: Arkansas & Delhon et al. (2004) & AY386265.1 \\
\hline 2 & VR634 & Pseudocowpox virus & Finland & Hautaniemi et al. (2010) & GQ329670.1 \\
\hline 3 & F00.120R & Pseudocowpox virus & Finland & Hautaniemi et al. (2010) & GQ329669.1 \\
\hline 4 & PCPV776 & Pseudocowpox virus & Austria & DS & HM589037.1 \\
\hline 5 & Shiraz1 & ORFV & Iran & - & KC534486.1 \\
\hline 6 & Shiraz3 & ORFV & Iran & - & KC534488.1 \\
\hline 7 & OV-SAOO/ORFD & ORFV & United States: Texas & Delhon et al. (2004) & AY386264.1 \\
\hline 8 & Shiraz2 & ORFV & Iran & - & KC534487.1 \\
\hline 9 & Egypt2006 & ORFV & Egypt & Mahmoud, Abdelrahman and Soliman (2010) & EU826136.1 \\
\hline 10 & Shiraz5 & ORFV & Iran & - & KC534490.1 \\
\hline 11 & OV-IA82/ORFA & ORFV & United States: Iowa & Delhon et al. (2004) & AY386263.1 \\
\hline 12 & NZ2 & ORFV & New Zealand & Mercer et al. (2006) & DQ184476.1 \\
\hline 13 & D1701 & ORFV & Germany & McGuire, Johnston and Sykes (2012) & HM133903.1 \\
\hline 14 & Shiraz4 & ORFV & Iran & - & KC534489.1 \\
\hline
\end{tabular}

ORFV, Orf virus; DS, direct submission.

(VR634), another PCPV from Finland (F00.120R) and then also to PCPV from Austria (PCPV776).

\section{Discussion}

Several procedures have been developed to detect ORFV, while most of them are time-consuming, costly and sometimes associated with low specificity, reduced sensitivity and with cross reactions (Inoshima et al. 2001; Khalafalla et al. 2015a; Kottaridi et al. 2006). Assays based on PCR are considered as rapid, sensitive and specific tests for identifying the causative agents of diseases (Andrade et al. 1983; Inoshima et al. 2001, 2002). Several PCR protocols have been described for detecting the DNA of PPV (Inoshima et al. 2000, 2001, 2002; Torfason \& Gunadottir 2002). Two target genes to generate PCR amplicons from CCE DNA for sequence analysis are the open reading frame ORF011 and ORF045 which encode VLTF-1 (Khalafalla et al. 2015b; Kottaridi et al. 2006). Sequencing of the suspected samples showed that MSOSH had close relation to PCPV from Finland (VR634) followed by another PCPV from Finland (F00.120R) and PCPV from Austria (PCPV776). Additionally, MSOKE had $99.77 \%$ and $82.13 \%$ similarity to Jodhpur and CE41 isolates, respectively. Khalafalla et al. (2015b) considered that camel ORFV isolates can be divided into two genetic clades including the Asian lineage of isolates from Saudi Arabia, Bahrain and India and the African lineage of isolates from Sudan, based on the sequence of the ORF011 gene among camels in Sudan. They showed that the camel ORFV is diverse from viruses close to PCPV and ORFV. Nagarajan et al. (2010) analysed and compared the sequence of Indian PCPV with several sequences related to ORFV, PCPV and BPSV available in the database. They showed that ORFV from different regions of the world had $92.3 \%-92.7 \%$ and $96.2 \%-96.5 \%$ sequence similarity with camel PCPV at the nucleotide and amino acid level, respectively. 


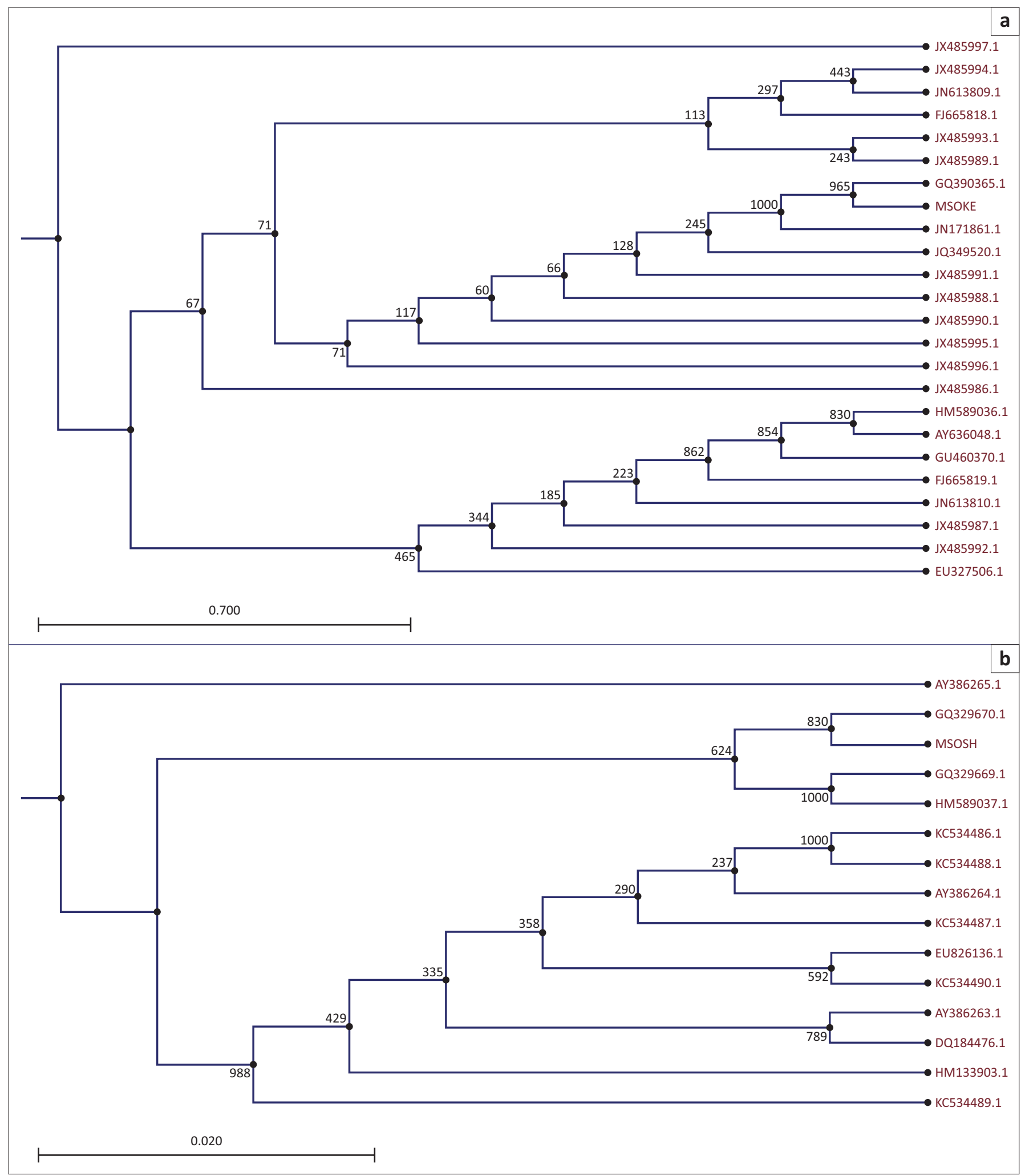

The numbers at each branch represent bootstrap values. The bar represents the genetic distance.

FIGURE 1: Phylogenetic analysis of the Orf virus based on the (a) ORF011 and the (b) ORF045 gene. The phylogenetic trees were constructed using the neighbour-joining algorithm in CLC Main workbench 5.5 with 1000 bootstrap replicates.

ORFV has previously been cultivated on cell cultures such as Vero, lamb testis (LT) and ovine testis (OA3.Ts), whereas the cell culture was done on chicken embryo fibroblast (CEF) in this study. It is because CPE includes cell detachment, rounded cells and aggregation of cells. Meanwhile, many researchers have studied the effects of ORFV on various cell cultures. Housawi et al. (2012) compared the immunogenicity and protective efficacy of three locally developed live ORFV vaccines in Vero cell culture. For production of a live attenuated vaccine against ORFV, a wild virus strain has been attenuated through serial passages on the primary CEF tissue cultures (Mercante et al. 2008). The isolation and 
attenuation of the virus in Iran would therefore be necessary for protection of camels. A recent study performed by Mombeni et al. (2013) in Iran reported severe cases of CCE that caused a morbidity and mortality rate of $70.6 \%$ and $6.0 \%$, respectively. This points to the potential importance of this disease in Iran. This study has indicated that ORFV with an apparent close similarity to PCPV can be a major cause of contagious ecthyma in Iranian camels.

\section{Acknowledgements}

The authors are thankful to Mrs Majidi from the Razi Vaccine and Serum Research Institute for her valuable contribution to this study. The authors are also indebted to Dr Shahriari and Dr Varshovi for their assistance in providing the samples. The authors would like to thank the authorities of Shiraz University for partial financial support of the project.

\section{Competing interests}

The authors declare that they have no financial or personal relationships that may have inappropriately influenced them in writing this article.

\section{Authors' contributions}

All authors contributed equally in all stages of the manuscript preparation and approved its final version.

\section{References}

Abrahao, J.S., Campos, R.K., Trindade, G.S., Guedes, M.I., Lobato, Z.I., Mazur, C. et al., 2009, 'Detection and phylogenetic analysis of Orf virus from sheep in Brazil: A case report', Virology Journal 6, 47. https://doi.org/10.1186\%2F1743-422X-6-47

Abubakr, M.I., Abu-Elzein, E.M., Housawi, F.M., Abdelrahman, A.O., Fadlallah, M.E., Nayel, M.N. et al., 2007, 'Pseudocowpox virus: The etiological agent of contagious ecthyma (Auzadyk) in camels (Camelus dromedarius) in the Arabian Peninsula, Vector-Borne and Zoonotic Diseases 7(2), 257-260. https://doi.org/10.1089/ vbz.2006.0627

Andrade, L.F., Villegas, P. \& Fletcher, O.J., 1983, 'Vaccination of day-old broilers against infectious bronchitis, effect of vaccine strain and route of administration', Avian Disease 27(1), 178-187. https://doi.org/10.2307/1590383

Chan, K.W., Yang, C.H., Lin, J.W., Wang, H.C., Lin, F.Y., Kuo, S.T. et al., 2009, 'Phylogenetic analysis of parapoxviruses and the C-terminal heterogeneity of viral ATPase proteins', Gene 432(1-2), 44-53. https://doi.org/10.1016/j.gene.2008.10.029

Dal Pozzo, F., Martinelle, L., Gallina, L., Mast, J., Sarradin, P., Thiry, E. et al., 2011 'Original findings associated with two cases of bovine papular stomatitis' Journal of Clinical Microbiology 49(12), 4397-4400. https://doi.org/10.1128/ JCM.05281-11

Davari, S.A., Sayyari, M. \& Mohammadi, A., 2013, 'Genetic analysis of the viral agents causing crust in small ruminants of Shiraz, Iran', Bulgarian Journal of Veterinary Medicine 16(3), 159-169.

Delhon, G., Tulman, E.R., Afonso, C.L., Lu, Z., de la Concha-Bermejillo, A., Lehmkuhl, H.D. et al., 2004, 'Genomes of the parapoxviruses Orf virus and bovine papular stomatitis virus', Journal of Virology 78(1), 168-177. https://doi.org/10.1128/ JVI.78.1.168-177.2004

De Oliveira, C.H., Assis, F.L., Neto, J.D., Oliveira, C.M., Lopes, C.T., Bomjardim Hdos, A. et al., 2012, 'Multifocal cutaneous ORF virus infection in goats in the Amazon region, Brazil', Vector-Borne and Zoonotic Disease 12(4), 336-340. https://doi. org/10.1089/vbz.2011.0725

Fleming, S.B., Wise, L.M. \& Mercer, A.A., 2015, 'Molecular genetic analysis of orf virus: A poxvirus that has adapted to skin', Viruses 7(3), 1505-1539. https://doi. org/10.3390/v7031505

Harvey, R., McCaughan, C., Wise, L.M., Mercer, A.A. \& Fleming, S.B., 2015, 'Orf virus inhibits interferon stimulated gene expression and modulation the JAK/STAT signaling pathway', Virus Research 28, 180-188. https://doi.org/10.1016/j. virusres.2015.06.014

Hautaniemi, M., Ueda, N., Tuimala, J., Mercer, A.A., Lahdenpera, J. \& McInnes, C.J. 2010, 'The genome of pseudocowpox virus: Comparison of a reindeer isolate and a reference strain', Journal of General Virology 91(Pt 6), 1560-1576. https://doi. org/10.1099/vir.0.018374-0
Hosamani, M., Bhanuprakash, V., Scagliarini, A. \& Singh, R.K., 2006, 'Comparative sequence analysis of major envelop protein gene (B2L) of Indian Orf viruses isolated from sheep and goats', Veterinary Microbiology 116(4), 317-324. https:// isolated from sheep and goats', Veterin
doi.org/10.1016/j.vetmic.2006.04.028

Housawi, F.M., Abuelzein, E.M., Gamee, A.A. \& Alafaleq, A.I., 2012, 'Comparative study on three locally developed live Orf virus vaccines for sheep in Saudi Arabia', Onderstepoort Journal of Veterinary Research 79(1), E1-E5. https://doi. Arabia', Onderstepoort Journal
org/10.4102/ojvr.v79i1.397

Inoshima, Y., Morooka, A. \& Sentsui, H., 2000, 'Detection and diagnosis of parapoxvirus by polymerase chain reaction', Journal of Virological Methods 84(2), 201-208. https://doi.org/10.1016/S0166-0934(99)00144-5

Inoshima, Y., Murakami, K., Wu, D. \& Sentsui, H., 2002, 'Characterization of parapoxviruses circulating among wild Japanese serows (Capricornis crispus)', Microbiology and Immunology 46(8), 583-587. https://doi.org/10.1111/j. 1348-0421.2002.tb02738.x

Inoshima, Y., Murakami, K., Yokoyama, T. \& Sentsui, H., 2001, ‘Genetic heterogeneity among parapoxviruses isolated from sheep, cattle and Japanese serows (Capricornis crispus)', Journal of General Virology 82(Pt 5), 1215-1220. https:// doi.org/10.1099/0022-1317-82-5-1215

Khalafalla, A.I., Al-Busada, K.A. \& El-Sabagh, I.M., 2015a, 'Multiple PCR for rapid diagnosis and differentiation of pox and pox-like diseases in dromedary camels', Virology Journal 12, 102. https://doi.org/10.1186\%2Fs12985-015-0329-x

Khalafalla, A.I., El-Sabagh, I.M., Al-Busada, K.A., Al-Mubarak, A.I. \& Ali, Y.H., 2015b, 'Phylogenetic analysis of eight Sudanese camel contagious ecthyma viruses based on B2L gene sequence', Virology Journal 12, 124. https://doi.org/10.1186\%2 Fs12985-015-0348-7

Klein, J. \& Tryland, M., 2005, 'Characterization of parapoxviruses isolated from Norwegian semi-domesticated reindeer (Rangifer tarandus tarandus)', Virology Journal 2, 79. https://doi.org/10.1186\%2F1743-422X-2-79

Kottaridi, C., Nomikou, K., Lelli, R., Markoulatos, P. \& Mangana, O., 2006, 'Laboratory diagnosis of contagious ecthyma comparison of different PCR protocols with virus isolation in cell culture', Journal of Virological Methods 134(1-2), 119-124. https://doi.org/10.1016/j.jviromet.2005.12.005

Li, H., Zhu, X., Zheng, Y., Wang, S., Liu, Z., Dou, Y. et al., 2013, 'Phylogenetic analysis of two Chinese orf virus isolates based on sequences of B2L and VIR gene', Archives of Virology 158(7), 1477-1485. https://doi.org/10.1007/s00705-013 1641-7

Lucinda, N., Inoue-Nagata, A.K., Kitajima, E.W. \& Nagata, T., 2010, 'Complete genome sequence of Brugmansia suaveolens mottle virus, a potyvirus from an ornamental shrub', Archives of Virology 155(10), 1729-1732. https://doi.org/10.1007/ s00705-010-0798-6

Mahmoud, M., Abdelrahman, K. \& Soliman, H., 2010, 'Molecular and virological studies on contagious pustular dermatitis isolates from Egyptian sheep and goats', Research in Veterinary Science 89(2), 290-294. https://doi.org/10.1016/j. rvsc.2010.02.019

McGuire, M.J., Johnston, S.A. \& Sykes, K.F., 2012, 'Novel immune-modulator identified by a rapid, functional screen of the parapoxvirus ovis (Orf virus) genome', Proteome Science 10(1), 4. https://doi.org/10.1186\%2F1477-5956-10-4

Mercante, M.T., Lelli, R., Ronchi, G.F. \& Pini, A., 2008, 'Production and efficacy of an attenuated live vaccine against contagious ovine ecthyma', Veterinaria Italiana 44(3), 543-547.

Mercer, A.A., Ueda, N., Friederichs, S.M., Hofmann, K., Fraser, K.M., Bateman, T. et al., 2006, 'Comparative analysis of genome sequences of three isolates of Orf virus reveals unexpected sequence variation', Virus Research 116(1-2), 146-158. reveals unexpected sequence variation', Virus
https://doi.org/10.1016/j.virusres.2005.09.011

Mombeni, E.G., Mombeini, M.G., Varshovi, H.R., Khalaj, M., Kenarkohi, M., Goudarzi, M. et al., 2013, 'Outbreak of contagious ecthyma in camels (Camelus dromedarius and Camelus bactrianus) in Southwest Iran', Revue d'elevage et de Medecine Veteterinaire des Pays Tropicaux 66(4), 113-115.

Mosadeghhesari, M., Oryan, A., Zibaee, S. \& Varshovi, H.R., 2014, 'Molecular investigation and cultivation of camelpox virus in Iran', Archives of Virology 159(11), 3005-3011. https://doi.org/10.1007/s00705-014-2169-1

Nagarajan, G., Ghorui, S.K., Kumar, S. \& Pathak, K.M., 2010, 'Complete nucleotide sequence of the envelope gene of pseudocowpox virus isolates from Indian dromedaries (Camelus dromedarius)', Archives of Virology 155(10), 1725-1728. https://doi.org/10.1007/s00705-010-0784-z

Rovozzo, G.C. \& Burke, C.N., 1973, A manual of basic virological techniques, PrenticeHall Inc., Englewood Cliffs, NJ.

Schmidt, C., Cargnelutti, J.F., Brum, M.C., Traesel, C.K., Weiblen, R. \& Flores, E.F., 2013, 'Partial sequence analysis of B2L gene of Brazilian Orf viruses from sheep and goats', Veterinary Microbiology 162(1), 245-253. https://doi.org/10.1016/j. vetmic.2012.10.031

Torfason, E.G. \& Gunadottir, S., 2002, 'Polymerase chain reaction for laboratory diagnosis of Orf virus infections', Journal of Clinical Virology 24(1-2), 79-84. https://doi.org/10.1016/S1386-6532(01)00232-3

Venkatesan, G., Balamurugan, V., Singh, R.K. \& Bhanuprakash, V., 2010, 'Goat pox virus isolated from an outbreak at Akola, Maharashtra (India) phylogenetically related to Chinese strain', Tropical Animal Health and Production 42(6), 1053-1056. https://doi.org/10.1007/s11250-010-9564-8

Zhang, K., Liu, Y., Kong, H., Shang, Y. \& Liu, X., 2014, 'Comparison and phylogenetic analysis based on the B2L gene of Orf virus from goats and sheep in China during 2009-2011', Archives of Virology 159(6), 1475-1479. https://doi.org/10.1007/ s00705-013-1946-6 